\title{
An Action Research on Improving Classroom Communication and Interaction in Social Studies Teaching
}

\author{
Mutlu Aksoy $\mathbb{D}^{1}$ and Tuncay Ceylan (D) $^{2}$ \\ ${ }^{1}$ Bayburt University, Department of Education, Bayburt 69000, Turkey \\ ${ }^{2}$ Ataturk University, Department of Education, Erzurum 25000, Turkey \\ Correspondence should be addressed to Mutlu Aksoy; mutluaksoy@yahoo.com
}

Received 4 April 2021; Revised 13 August 2021; Accepted 15 September 2021; Published 12 October 2021

Academic Editor: Ehsan Namaziandost

Copyright ( $) 2021$ Mutlu Aksoy and Tuncay Ceylan. This is an open access article distributed under the Creative Commons Attribution License, which permits unrestricted use, distribution, and reproduction in any medium, provided the original work is properly cited.

\begin{abstract}
The aim of this research is to reveal how communication and interaction in classrooms can be enhanced with the communicative approach education provided for social studies teachers. The participants of this research were five social studies teachers working at secondary schools and their $7^{\text {th }}$ grade students, $N=110$. The data collection tools adopted in this research were video and audio recordings, documents, semistructured interview forms, and stimulated recall interview forms. The data obtained from recordings of lessons were analyzed using the communicative approach, and the data obtained from document review and interview were analyzed using the content analysis method. The results of the study show that social studies curriculum contains items that require both dialogical and authoritative discourses and that the course books are prepared accordingly, but teachers as the practitioners of the program do not conduct their lessons accordingly. Instead, all the teachers participating in the research used only authoritative (interactive/noninteractive) approaches and they did not include dialogical (interactive/noninteractive) approaches at all. This situation, which is seen as a problem in terms of conducting successful in-class communication and interaction, has been solved in three action cycles with one of the teachers. The teacher who used only authoritative (interactive/noninteractive) approaches in her lessons prior to the trainings started to include dialogical (interactive/noninteractive) approaches too. It was also observed that the teacher's impression of the lessons carried out by adopting the communicative approach model was positive. As a result of the research, it was concluded that the communicative approach model is applicable in the social studies course. It can be said that the trainings given to the teachers created awareness about the use of the communicative approach model in classroom communication and interaction and provided benefits in diversifying discourse styles.
\end{abstract}

\section{Introduction}

The current developments in science and technology, the changing needs of the individuals and the society, and the advancements in learning-teaching theories and approaches have directly affected the roles expected from educated individuals [1]. Because, education holds a key role in dealing with the problems that emerge with the rapidly changing world conditions. The desire to raise active citizens who are compatible with the changing world conditions in parallel to the new knowledge and values have triggered education reforms in Turkey, as is the case in the other parts of the world. Because there is a need for entrepreneurial, empathetic individuals who contribute to the society and culture producing knowledge and using this knowledge functionally in life by means of communication, critical thinking, questioning, and problem-solving skills, rather than individuals who have just enough knowledge to do what they are told to do [2]. Accordingly, the current social studies curriculum in Turkey was designed to adopt a research and inquiry-based learning strategy. With the implementation of this new curriculum, the teaching style required a reformulation by putting extra emphasis on classroom discourse where student contribution is of crucial importance because the in-class activities in this new system provide a chance for the students to meet and think about new/different perspectives [3]. In this new education system, an instructor's knowledge of the subject matter is critical, but 
not sufficient [4]. This has changed the teacher role from the knowledge transmitter to guide and facilitator and the student role from knowledge receiver to user, researcher, questioner, and explainer of technology. Although in theory the teacher is withdrawn from the center, it is not easy to abandon the traditional teacher-centered approach in practice. The problem is, as the implementers of the program, teachers are often unaware that they are conducting a teacher-centered educational process. Reasons such as anxiety about classroom management and syllabus and inability to abandon habits and failure to adapt to change cause teachers to display an authoritarian style in classroom communication. For this study, determining the types of the communicative approach applied by teachers in social studies classrooms is considered to be of crucial importance for improvement. The aim of this research is to reveal how in-class communication and interaction in social studies teaching can be improved with the communicative approach training provided for teachers. Our research questions are as follows. (1) What is the current situation regarding the use of communicative approaches in social studies education? (2) What kind of a change did the action plans create in in-class communication and interaction? (3) What are the teacher's views on the social studies course, which is conducted by adopting the communicative approach model? This study aims to answer these questions with reference to the existing literature.

1.1. Communicative Approach. The communicative approach developed by Mortimer and Scott [5] is a model that focuses on the types of discursive interactions that take place between teachers and students (including those between students) in the classroom and tries to explain how these types of interaction play a role in the meaning-making and learning processes. This approach has two dimensions: dialogic/authoritative and interactive/noninteractive. By synthesizing these two dimensions, four different classes of the communicative approach, which are interactive/dialogic, interactive/authoritative, noninteractive/dialogic, and noninteractive/authoritative, have been revealed. The two strands of this approach are presented in Table 1.

According to Mortimer and Scott [5], the way to convert the language that students use in daily life into scientific language is only possible through the use of communicative approaches together. In order for the learning process to succeed, both dialogic (interactive/noninteractive) and authoritative (interactive/noninteractive) discourse elements must be included in classroom communication and interaction. According to Lehesvuori et al. [6], it is important for the teacher to be aware of different discursive strategies and their functions in developing learning. In some cases, the teacher should provide basic information with an authoritative approach, and in others, she/he should encourage the students to think with questions, examples, and expressions. When considered from this perspective, teachers are expected to diversify the forms of discourse they use in the classroom in order to raise individuals who are knowledgeable and able to question, think critically, and solve problems. Teachers must be aware of the communicative approach model in order to create such a classroom environment.

The "Communicative Approach Model" has attracted the attention of many researchers, especially in the fields of science and mathematics education [5-20]. Many of these studies suggest that authoritative (interactive/noninteractive) discourse is dominant in classroom communication and interaction and that dialogic (interactive/noninteractive) discourse is used little or not at all. Teachers usually conduct their lessons by making explanations and by asking students questions that are closed-ended or targeting predefined answers. In some of these studies, [6, 8, 9, 21, 22], when teachers were given a training about the communicative approach, they could change the form of discourse they use in the classroom and they started to include both authoritative (interactive/noninteractive) and dialogic (interactive/noninteractive) discourses in their lessons proportionally. In addition, Watters and Diezmann [20] found that diversifying classroom discourse increases students' interest in the lesson. In each of these studies, it is emphasized that the communicative approach model improves classroom communication and interaction. Although it is widely studied in science education, there is no study (to our knowledge) that has researched the effect of the communicative approach model on social studies teaching. In light of the above-mentioned explanations and discussion, whether the communicative approach model can be applied in social studies teaching, what problems will be encountered if it is applied, and whether it is possible to overcome these problems have aroused curiosity in the researcher. Thus, a study was conducted to improve communication and interaction in the classroom in social studies teaching. The main aim of this study is to reveal how communication and interaction in classrooms can be enhanced with the communicative approach training provided for social studies teachers.

\section{Methods}

In this study, practical/mutual collaborative/deliberate mode of action research, which enables researcher and teacher collaboration, was applied. In this mode, the researcher and the participant teacher come together to identify possible problems, the underlying causes, and possible solutions [23]. They collaboratively identify the problems that occur during the practice of each action plan, evaluate these problems, and try to find solution. This process aims to improve the participant's application and presentation in the classroom. The communication flow begins with the collaboration of the researcher and participant (teacher) and then flows from the participant to students.

In this study, the action research steps outlined by Johnson [24] were adopted. Accordingly, the action research process is made up of various steps which are (1) identifying the problem, (2) planning the data collection process (i.e., how and how often), (3) collecting and analyzing data, (4) preparing an action plan based on the findings obtained, and finally (5) reporting/sharing the findings. The dynamic and 
TABLE 1: Four classes of the communicative approach [5].

\begin{tabular}{lcc}
\hline & Interactive (multiple voices) & Noninteractive (one voice) \\
\hline $\begin{array}{l}\text { Dialogic (different } \\
\text { points of views) }\end{array}$ & $\begin{array}{c}\text { Interactive/dialogic (both the teacher and the students } \\
\text { actively participate and are open to different } \\
\text { perspectives to construct knowledge jointly) }\end{array}$ & $\begin{array}{c}\text { Noninteractive/dialogic (at the end of the speech series } \\
\text { that are open to different perspectives, the teacher } \\
\text { chooses different ideas from students and shares these } \\
\text { ideas by referring to the student) }\end{array}$ \\
$\begin{array}{l}\text { Authoritative (one } \\
\text { single point of view) }\end{array}$ & $\begin{array}{c}\text { Interactive/authoritative (the students' opinions are } \\
\text { expressed as long as they are coherent with the } \\
\text { teacher's point of view) }\end{array}$ & $\begin{array}{c}\text { Noninteractive/authoritative (the teacher focuses on a } \\
\text { specific point of view and conveys information through } \\
\text { direct instruction without interacting with students) }\end{array}$ \\
\hline
\end{tabular}

flexible structure of action research allows for a distinctive planning for each study. This current study was designed in a dynamic and flexible structure that focuses on solving the problems that arose during the application rather than a predetermined, fixed process.

This study followed the action research cycle shown in Figure 1. First, the current situation and problem were determined. In the current situation, teachers frequently used authoritative (interactive/noninteractive) approaches, while they almost never used dialogic (interactive/noninteractive) ones. This situation was seen as a problem in terms of conducting successful classroom communication and interaction, and it was decided that this problem could be solved through an action research.

2.1. Participants. The participants were five social studies teachers working at elementary schools in the northeast part of Turkey, their $7^{\text {th }}$ grade students, $N=110$, the researcher, and the two members of the validity committee. The schools where the research was conducted were selected with convenience sampling. In this sampling method, the researcher chooses the study group among the people who could be reached quickly and easily [25]. This selection, the volunteerism of the teachers, the consent of the students' families, the easy communication between the researcher and the participating teachers, and the appropriate course hours for the teachers and the researcher were taken into consideration. One single teacher who participated in the second stage of the research (i.e., action research) was determined by the purposive criterion sampling method [25]. Criteria such as the teacher's volunteerism, ability to spare time, being open to professional development, and aiming to improve classroom communication and interaction were considered.

2.2. Data Collection. Action research aims to understand some elements and situations in the teaching environment by collecting data [24]. The data collection tools used in this study were video cameras, audio recorders, and semistructured interview form. During the data collection phase, two video cameras and an audio recorder were used to keep the recordings as detailed as possible. As shown in Figure 2, one of these cameras is placed at the front wall facing the students and the other one is at the back facing the teacher.

The data collection ended up with a database containing 75 hours of video recordings in the initial case study and a total of 40 hours of video recordings in the following action research.
Social studies curriculum and social studies textbook were used as secondary data sources. Special purposes (18 items) in the social studies curriculum, 27 basic skills, 31 learning outcomes within the framework of 7 learning areas for $7^{\text {th }}$ graders, and 10 points that were expected to be considered in the implementation of the program were examined in terms of the communicative approach. The preparation questions, information delivery, classroom activities, and question-answer sections in the social studies textbook were examined in the context of the communicative approach.

At the end of the action research, a semistructured interview was held with the teacher, in order to reveal how she experienced this process. In this meeting, she was asked to share her experiences, thoughts and evaluations regarding the training, planning, implementation, and reorganization stages of the action research.

In this study, the recorded teaching-learning process was examined by the researcher in terms of the communicative approach, and the problems experienced by the teacher during the application were listed. The video recordings showing these problems identified by the researcher were first watched and evaluated with the validity committee members, and possible solutions were discussed. Later, the researcher met the teacher and watched these video extracts. Stimulated recall interviews were used as training materials in seminars. The teacher was shown sample video clips from her lessons illustrating discourses that prevent in-class communication and interaction and information was given on how to overcome these obstacles.

\subsection{Data Analysis}

2.3.1. Discourse Analysis. The audio-visual data were analyzed using the discourse analysis (DA) method in relation to the communicative approach types developed by Mortimer and Scott [5]. In DA, the researcher starts by searching for answers to the questions "Who talks how?" "Who listens how?" and "Who keeps silent?" According to Sözen [26], it is possible to define DA in three different dimensions. In the first one, DA deals with the use of language. In the second one, it deals with the functions of language in terms of explanation, understanding, and interpretation. In the last one, the analysis is pragmatic, that is, the linguistic features are studied in order to understand what they do in discourse. In this study, the researcher has adopted the third (pragmatic) dimension of DA aiming to find out how conversation is organized by analyzing the I-R-E and I-R-F 


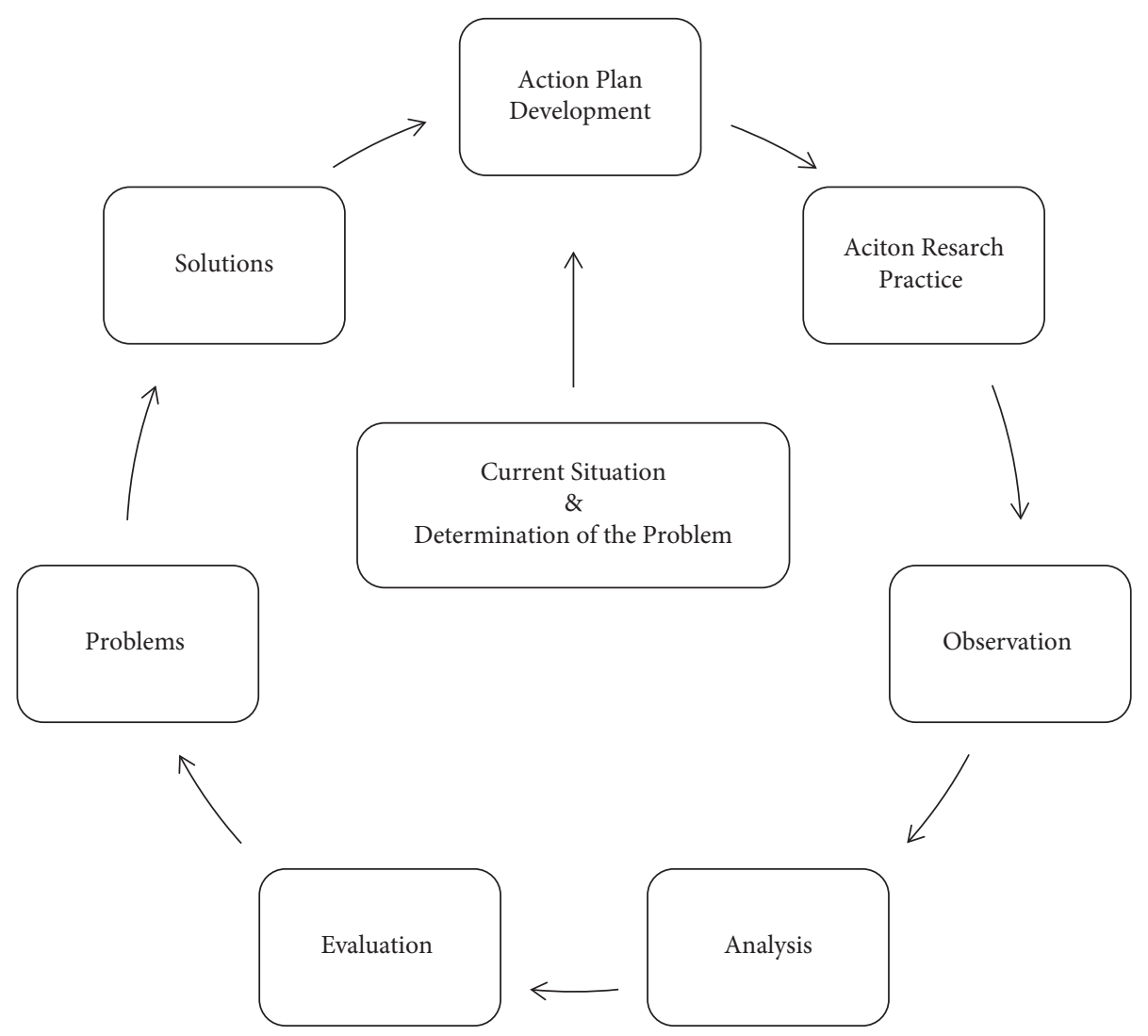

FIGURE 1: The action research cycle.
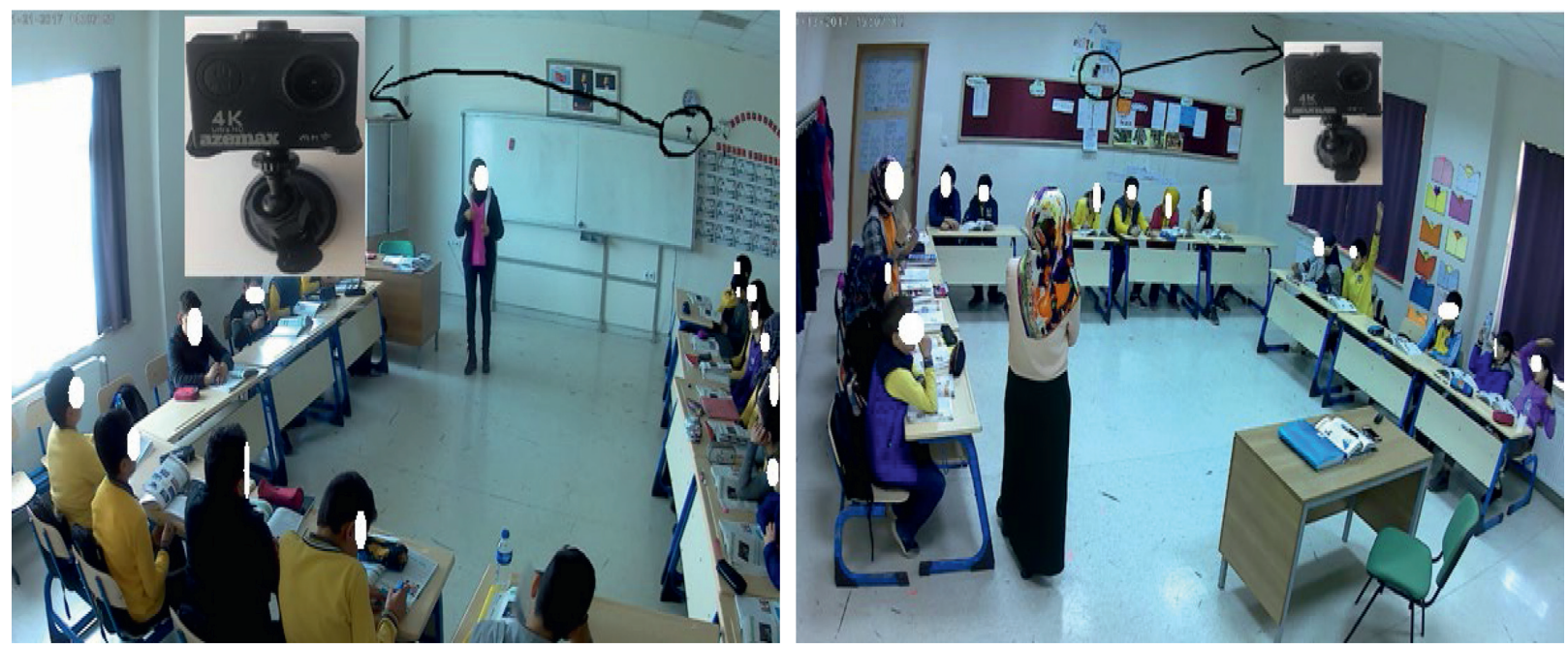

Figure 2: Placement of the cameras.

interaction patterns. He evaluated the findings he obtained through DA in terms of the communicative approach by coding them in interactive/noninteractive dialogic and interactive/noninteractive authoritative dimensions.

2.3.2. Content Analysis. The content analysis method was used in the analysis of the curriculum and textbook documents and in the analysis of the semistructured interview. According to Miles and Huberman [27], two of the pioneers of the content analysis coding system, the data collected in the form of observation, interview, and document review are initially complex structures piled on top of each other. With content analysis, the researcher organizes the data stack under the codes determined by preliminary analysis and transforms it into an easy-to-understand form.

At the document analysis phase, the contents of the curriculum and the textbook were analyzed and grouped under four codes which are interactive/authoritative, 
interactive/dialogic, noninteractive/authoritative, and noninteractive/dialogic. While analyzing the interview data, first, the frequently repeated items were identified as codes, these codes were collected into common categories considering their frequency, and finally, umbrella themes were formed.

2.4. Ethical Consideration. The researcher visited the schools affiliated to the Bayburt Provincial Directorate of National Education, introduced himself to school administrators and social studies teachers, gave information about the purpose and process of the research, and requested them to take part in the study. After determining the schools and teachers who voluntarily accepted to participate in the study, official permission was obtained from the Provincial Directorate of National Education through the institute to which the researcher is affiliated. After the necessary permissions were obtained, detailed information was given to the teachers about the research process; then, a "participant information and consent form" was signed. Since the students were underage, their parents signed the ethical consent forms on their behalf. Participation was voluntary. Participants were identified by pseudonyms and code names for privacy purposes. In the visual data, the faces of the participants were anonymized.

\section{Findings}

3.1. Current Situation. The current social studies curriculum requires both dialogic and authoritative discourse in terms of special purposes, basic skills, learning outcomes, and issues to be considered in the implementation of the program; the textbook meets these requirements; but the teachers as the implementers of the program did not conduct their lessons accordingly. It was observed that all teachers participating in the study used only authoritative (interactive/noninteractive) approaches in the social studies teaching environment and never included the dialogic (interactive/noninteractive) ones.

To check whether the communication and interaction in social studies lessons were implemented as stipulated by the curriculum, five-week lessons of five voluntary social studies teachers (i.e., fifteen hours each) were recorded. In order to minimize the observer's paradox, the recordings of the first two weeks were not included in the analysis. The data obtained from the last three weeks were analyzed using DA, and the findings regarding the types of the communicative approach used are shown on the graphs.

When Figure 3 is examined, it can be seen that they only used authoritative (interactive/noninteractive) discourse in their lessons, and they did not include dialogic (interactive/ noninteractive) discourse at all. This raised a need to design an action research to promote the use of all for communicative approaches together.

3.2. Action Research. All the teachers who participated in the first stage of the study were offered to participate in the action research, which is the second part of the study. Only one of them volunteered. This teacher was trained on action research and the communicative approach model. Communicative approach training lasted 8 weeks, including 4 weeks of training seminars and 4 weeks of article reading and interpretation. After the trainings, the action process started.

3.2.1. The First Action Cycle. The types of the communicative approach used by $\mathrm{T} 5$ in her lessons after the first action plan (i.e., the trainings) are shown in the graphics.

Figure 4 shows that she used noninteractive/authoritative (14.25\%), interactive/authoritative (64.25\%), noninteractive/dialogic (2.29\%), and interactive/dialogic $(0.71 \%)$ discourse. $18.50 \%$ of the lessons consisted of the sections described as "others." It is obvious from the graph that T5 developed at diversifying the classroom discourse style and began to use the dialogic (interactive/noninteractive) communicative approach, albeit insufficiently, in addition to authoritative (interactive/noninteractive) one. Following is an extract that exemplifies a section of authoritative (interactive/noninteractive) discourse that T5 frequently uses in her lessons and dialogic (interactive/noninteractive) discourse that she uses very little.

\section{Extract 1:}

(1) T5: now, factors affecting the distribution of population in Turkey. We will examine these factors in two parts, natural and human. Apart from that, most importantly, you will learn how to interpret the graphics here. Okay? We will take a look at what features or information we are looking for about the population of a place from the graphs. Okay? Well, let us get someone to read the passage ( 6 students raise hands). Who wants to read?

(2) S?: teacher! $(x)$ says she/he has never read before (in the classroom)

(3) T5: no! We always let you all read out loud. There is no such thing. You can read, S11.

(4) S11: okay (I am starting). Teacher, we have already answered the following question.

(5) T5: (yes, now)

(6) T5: go through it again quickly. So that we will remember it (Okay? As a reminder). We need to link the two subjects.

(7) S11: (not knowing the population of our country)

(8) T5: we cannot directly start from the middle of the topic

(9) S10: you said "not knowing"

(10) S11: what is the importance of knowing the population of our country? Please say.

(11) S9: can I say? (raising her hand)

(12) T5: okay. (1.3) She asked a question. "Why is it important to know the population of our country?" Let us hear one or two answers briefly; we cannot spend time on everyone's answer. We are revising what we already know. Let us remember. Yes. 


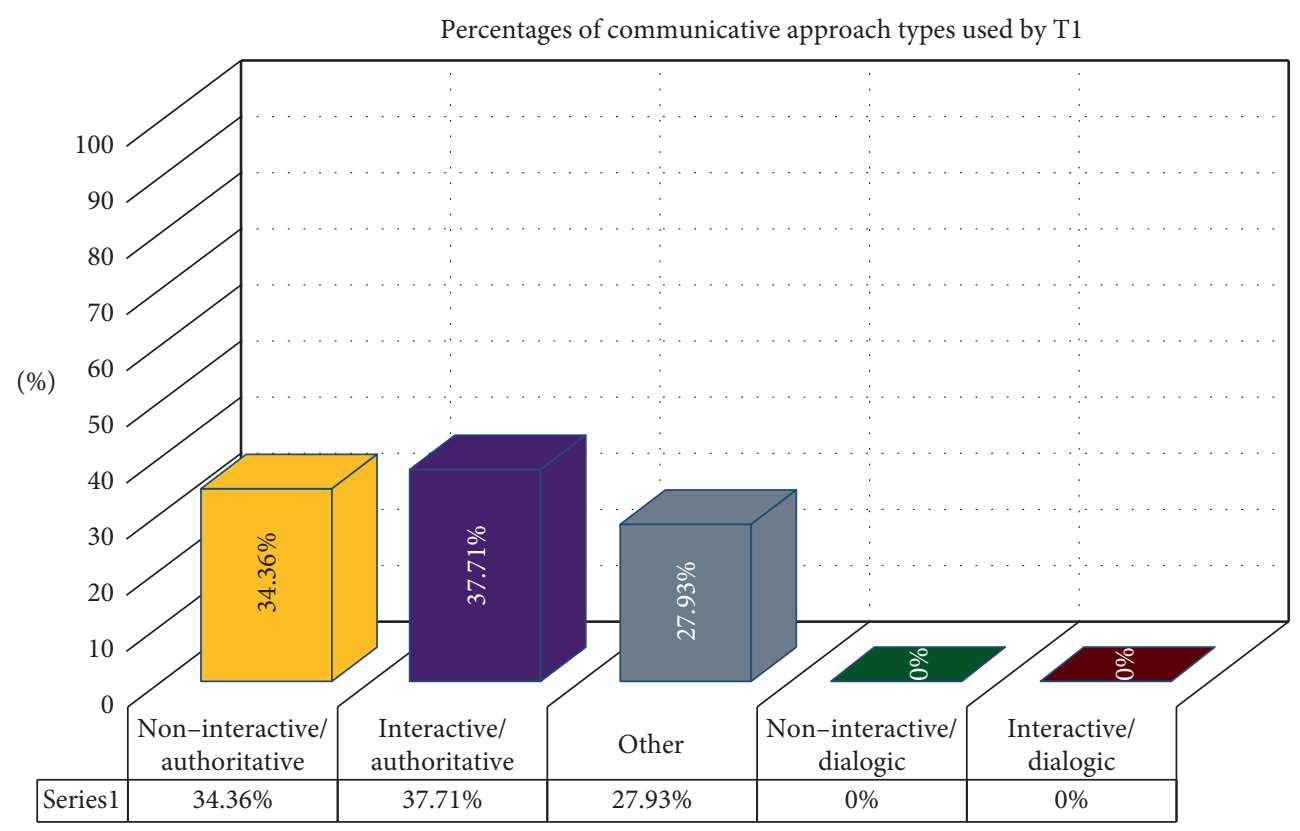

(a)

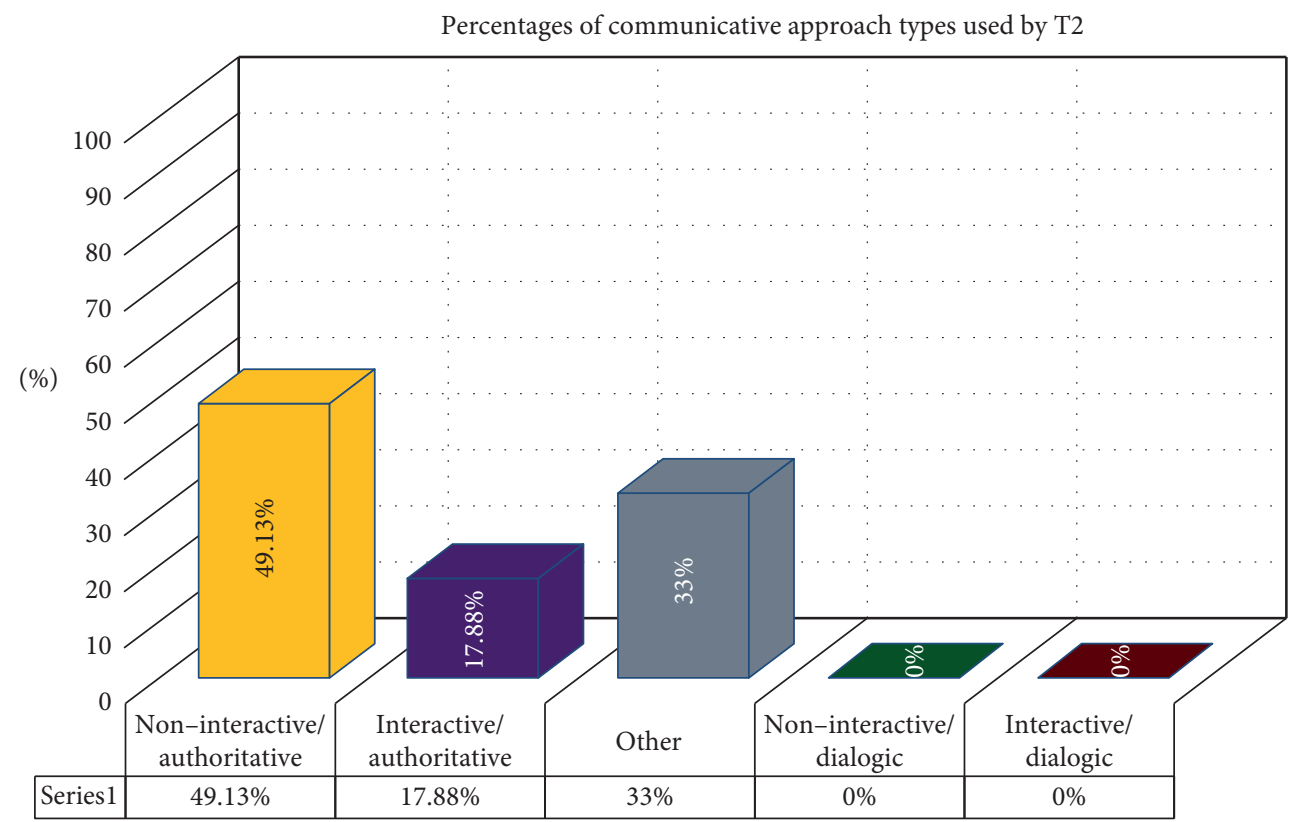

(b)

Figure 3: Continued. 


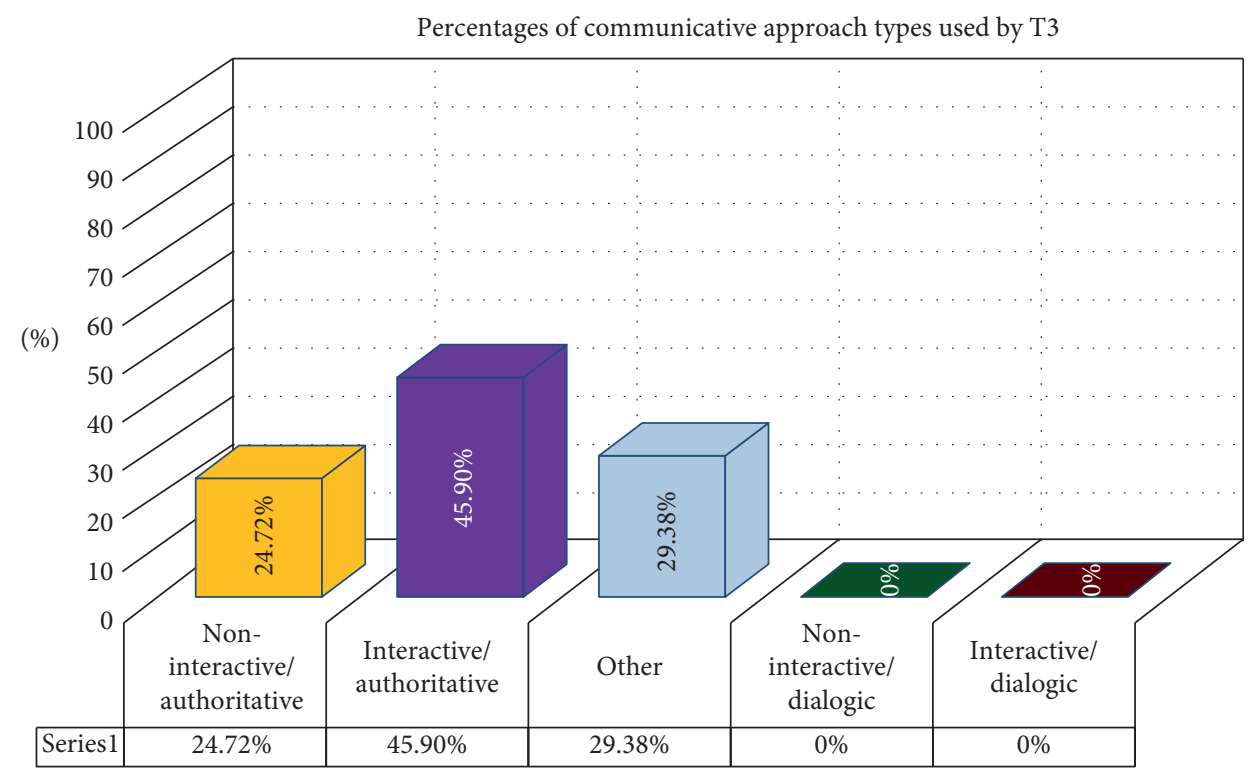

(c)

(d)

Figure 3: Continued. 


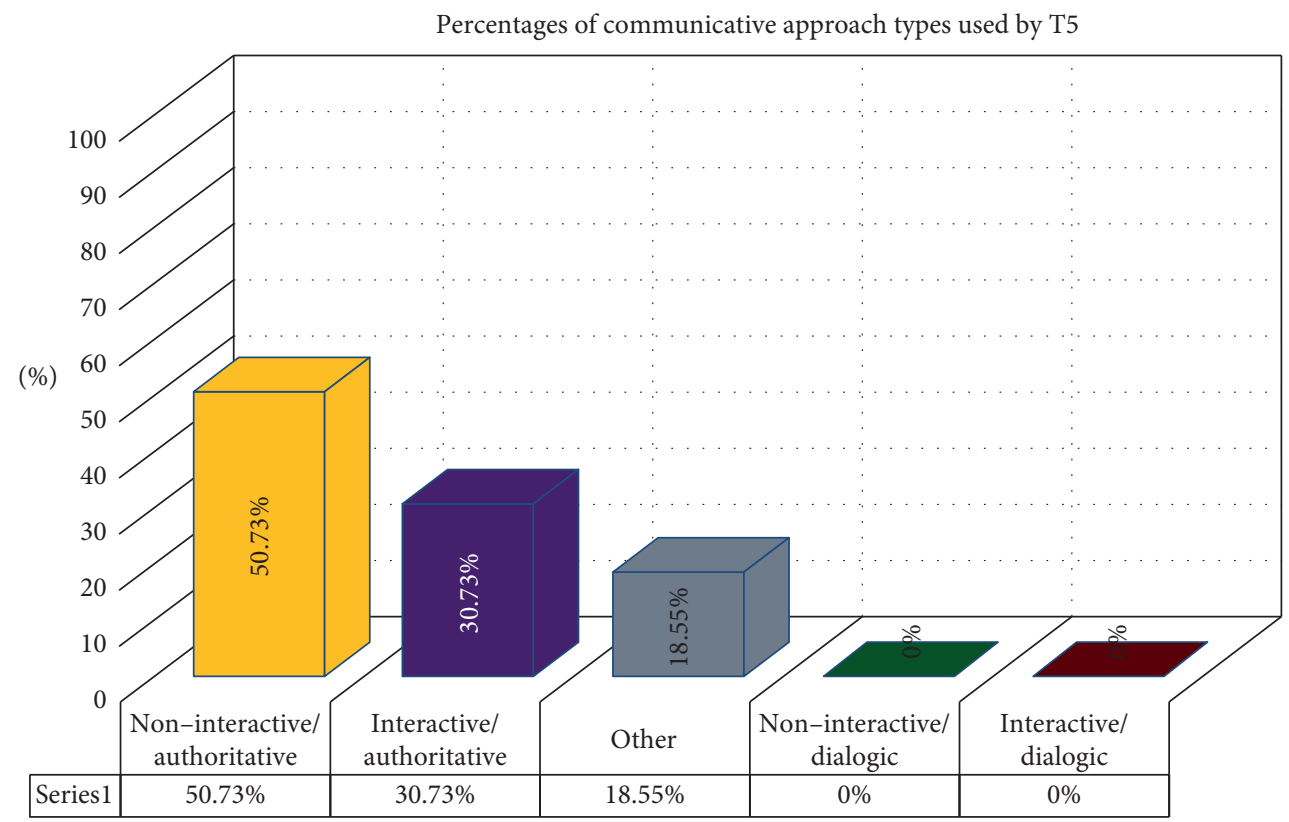

(e)

Figure 3: Percentages of communicative approach types used by T1, T2, T3, T4, and T5. (a) Percentages of communicative approach types used by T1. (b) Percentages of communicative approach types used by T2. (c) Percentages of communicative approach types used by T3. (d) Percentages of communicative approach types used by T4. (e) Percentages of communicative approach types used by T5.

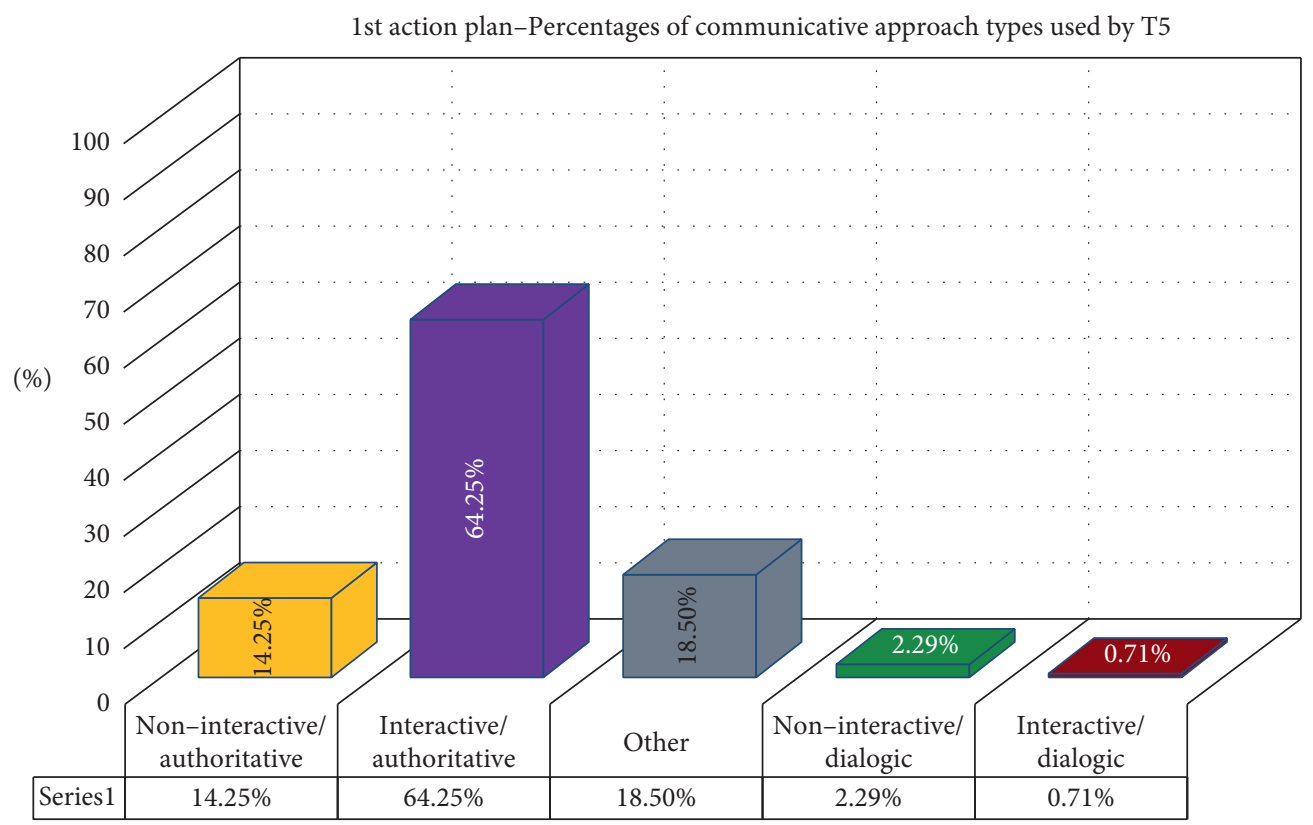

FIgURE 4: $1^{\text {st }}$ action plan-percentages of communicative approach types used by T5.

(13) S14: teacher, (0.6) they can make things, institutions and organizations according to the number of people.

(14) T5: so you say according to the number of people, what does the state give? You say it offers service, right? He says according to the number of people, the state builds institutions and organizations that people need, said your friend. Yes, does anyone disagree? (1.1) Yes, tell the answer S9.
(15) S9: hospitals and transportation are provided, teacher.

(16) T5: so what does the state do? What does providing hospitals and transportation mean?

(17) S9: let us say, hospital-hospital here is for 60 thousand people, but the population of Bayburt 100 thousand people. The state builds a hospital and does divides.

(18) S3: according to the population 
(19) S9: yes, teacher

(20) T5: so, you say it builds hospitals according to the population and then patients are divided between hospitals?

(21) S9: yes, teacher

(22) S3: for example, there is no private hospital in Bayburt

(23) T5: okay, let me ask something, S3. Why cannot there be a private hospital in Bayburt?

(24) S2: no, there are no doctors, let alone the private hospitals.

(25) T5: if there is a hospital, would there be doctors?

(26) S2, S3: yes, there would be

(27) T5: then, would there be hospitals? Okay, let me say something. Another topic. (1.2) Do you think your needs are fully met when you go to the hospital?

(28) S3, S7, S14: no

(29) T5: so, does your turn come quickly? Or you want (inaudible)

(30) S3, S9, S14: (inaudible)

(31) T5: raise your hands. There is another topic here. Yes, S3?

(32) S3: teacher, now, there are not many people in the queue in small cities with small populations. But, for example, there is Farabi Hospital in Trabzon. When we compare this hospital with that one, there is a huge difference.

(33) T5: but, are hospitals built according to the population?

(34) S7: yes.

(35) T5: for example, have you seen the new hospital being built? Why are they building it? S8

(36) S9: because it (the old one) is not sufficient

(37) T5: let S8 say it

(38) S8: because it is not sufficient

(39) T5: why is it not sufficient?

(40) S8: because it is very crowded whenever we go there. We have to wait around one to two hours.

(41) T5: you wait in the queue. You say that the state built a new hospital in Bayburt because they thought that the old one is not sufficient? Is that right?

(42) S1, S3, S4: right

(43) T5: I hope that it will be sufficient. But, even if there were private hospitals, do you think our citizens would prefer them?

(44) S3, S6, S9: they would, teacher.

(45) T5: they could, you mean. I think so. Why? Because there really is a need for it. The nearest private hospital is in Erzurum or Trabzon. They already send the patient to Erzurum or Trabzon when needed. Is that right?

(46) S17: is there one in Erzincan too, teacher?

(47) T5: there is in Erzincan. But people generally go to Erzurum or Trabzon. Okay. Then, your friends S5 and S14 said that the state builds some institutions according to the population. After them, S9 added the numbers of hospitals increase parallel to the population growth. Because the hospital in Bayburt was insufficient, there was a crowd. So, the state is building a new hospital because the current one cannot meet our needs. Apart from this, why is it important to know the population of our city or country? How does it help us? Yes, S17?

(48) S17: banknotes are printed accordingly teacher, depending on the number of people

(49) S14: no

(50) T5: banknotes are printed? (Explain this.) What do you mean?

(51) (noise)

(52) S17: teacher let us imagine that they do not take a census. If they do not, let us imagine that they printed 1000 banknotes, who will they belong to?

(53) S11: employees will get them

(54) S17: will only the employees get them?

(55) S11: yes teacher

(56) T5: they take the census and print money accordingly, you say

(57) S17: yes teacher

T5 starts the lesson with noninteractive/authoritative discourse (line 1). After informing the students about the subject she will cover in the lesson, she asks S11 to read the preparation section in the book. This section asks the question "Why is it important to know the population of our country? Tell me." This is an open-ended question to get the students' opinions and is expected to be handled with dialogic discourse. However, in this section, T5 guides students to find the correct answer (interactive/authoritative) by sometimes making explanations (lines 12, 43, and 45), sometimes asking close-ended questions (lines 20, 23, 27, 29, and 33), and sometimes asking confirmation questions such as "Okay?," "Is it right?," "Is not it?" (lines 25, 41, and 45). After listening to the answers, the teacher selects the relevant ones and shares them with the whole class referring to the student (noninteractive/dialogic) (line 47). In the only part where the lesson is interactive/dialogic, the teacher starts the discourse by asking an open-ended question (line 47) and selects S17 as the next speaker. S17 gave a short answer first (line 48). T5 asks S17 to expand on his answer (line 50) and he tries to explain what he means with an example (line 52). So, it is obvious from this and similar examples that T5 starts to use dialogic (interactive/noninteractive) discourse together with the authoritative (interactive/noninteractive) one, but way less than required by the syllabus and the coursebook. Figure 5 illustrates the list of problems and solutions which came up as a result of the $1^{\text {st }}$ action plan.

3.2.2. The Second Action Cycle. The types of the communicative approach used by $\mathrm{T} 5$ in her lessons after the second action plan are shown in Figure 6.

Figure 6 shows that she used noninteractive/authoritative $(20.40 \%)$, interactive/authoritative $(33.98 \%)$, noninteractive/dialogic (3.92\%), and interactive/dialogic (5.40\%) discourse. $36.31 \%$ of the lessons consisted of the sections described as "others." From this perspective, it can be 


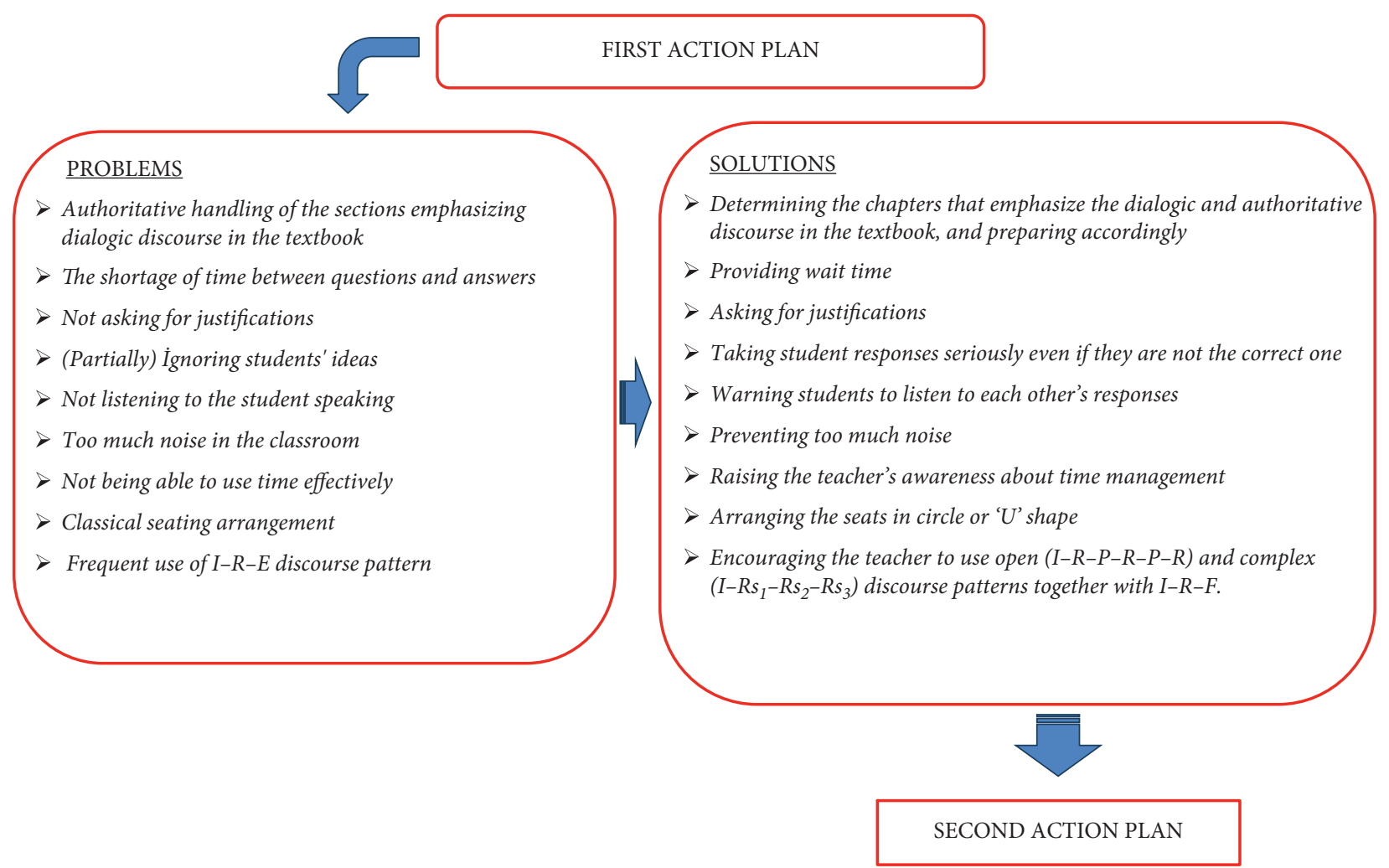

FIGURE 5: $1^{\text {st }}$ action plan-problems and solutions.

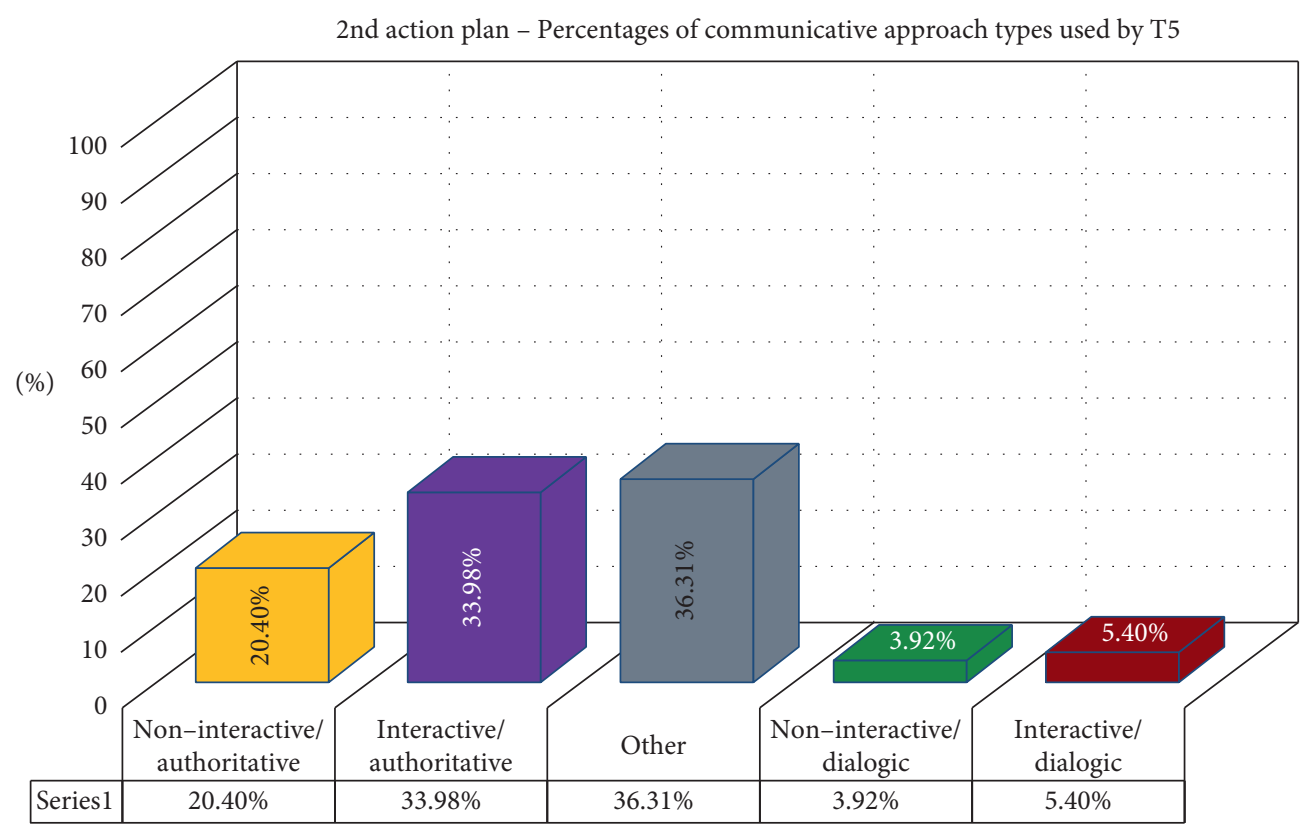

FIGURE 6: $2^{\text {nd }}$ action plan-percentages of communicative approach types used by T5. 
inferred that T5 has developed in terms of diversifying the classroom discourse style and has started to use the dialogic (interactive/noninteractive) communicative approach, albeit insufficiently, in addition to authoritative (interactive/ noninteractive) in her lessons. A lengthy dialogue exemplifying these discourses is given in detail.

\section{Extract 2:}

(1) T5: well, what is our title? (Where you were born or where you get full?)

(2) S3, S?: (Where you were born or where you get full?)

(3) T5: where you were born or where you get full? I am sure there are those among you who have already heard this from their elders.

(4) S?: yes

(5) T5: you have never heard it, S11?

(6) S11: (shakes his head no)

(7) T5: has anyone heard it before?

(8) S15, S17: I have

(9) T5: what do you think it means S17?

(10) S17: teacher, yesterday I was talking to my grandfather (noise). Whatever

(11) T5: just a second! Look! S17 is talking about something! We started the lesson already!

(12) S12: teacher I closed it (he was playing with the water bottle)

(13) S17: teacher I think, for example, as they say, it would be better if I could go to the place where I was born. Which one do you prefer, where you were born or where you live off? I think it means this.

(14) S3: (Teacher,)

(15) T5: (Means so) your friend says. The place where you were born, or where you live off. Any other ideas?

(16) S3: I have, teacher. (Teacher!)

(17) T5: (Is that all?) What do you think? Yes (Pointing to $\mathrm{S} 3$ ).

(18) S6: (Teacher!)

(19) S3: teacher, here, where you were born means your hometown. Or do you live in a big developed city? Do you prefer to live in your hometown or a big city like Istanbul?

(20) T5: you mean your hometown is an underdeveloped place. Do you prefer your hometown or a developed city? Do you think so? Ok, we will see in the passage. Yes.

(21) S10: teacher I think, for example, someone was born in Turkey. But went to Australia to work. Got a job there. Does that person prefer Turkey or Australia?

(22) T5: what did she/he do there? Got a job. Got education there, you say. You think so.

(23) S10: yes

(24) T5: okay, we will see. Do not forget this question.

(25) S3, S5: shall I read?

(26) T5: do not forget the question. Do you have a different opinion, S1? Yes.
(27) S1: teacher you know they move from where they were born, that might be why. For example, they were born and grown up at a place and they moved because that place might have inadequate opportunities.

(28) T5: that is why they moved from their birthplace to somewhere else. That is why we call "where they get full." You think so. We will see in a minute. Yes S5?

(29) S5: (Reading from the book) What can be the reasons for human beings to move?

(30) T5: okay. The question is "What can be the reasons for human beings to move?"

(31) S10: teacher

(32) T5: think about this.

(33) : (1.2)

(34) T5: everybody think about it first. (1.6) Wait until I write, think about it, okay? Is there anyone who does not know this concept? In this lesson, we will discuss the concept of migration from different angles. What does immigration mean? Why do people migrate? What are the reasons for immigration? And what are the types of migration? We will not talk about one single form of migration; there are various types of it. We will be dealing with migration from different angles. Deal? The title of the lesson and the title of the subject already reveal the concept of migration? Actually, we asked a question and S17 said that, rather than where we were born, the place where we make our living. I think so, said S17. I agree with him. But our friend, S3, said that he disagrees. Rather, the place where we were born may be an undeveloped place, but we may prefer a developed place. This will be one of the opinions but does not cover the exact sentence. What did S10 say?

(35) S10: for example, in Australia, teacher.

(36) T5: he said, originally from Turkey, but got education in another country and works there. For example, he might be living in Australia, he said. (1.9) This might be right, friends. These are all possibilities. Both S3 and S17 might be right. For example, if I were asked, I would answer like S17, but what S3 said is also another reason for migration. And what S3 said is?

(37) S3: right

(38) T5: right answer. From different perspectives, we will handle the immigration concept from this perspective. Now, we have asked our question. We asked "Why do people immigrate?" (1.3) Why do people immigrate?

(39) S???: teacher! Teacher!

(40) T5: what is immigration?

(41) S?: from one place to another

(42) S3: immigration means moving from one place to another.

(43) T5: yes. Do you think so, S3? We should raise our hands, right? We do not talk from our seats. S9 has raised his hand. 
(44) S9: teacher, immigration. (2.2) Can I explain with animals, teacher?

(45) T5: explain

(46) S9: teacher, birds move to one place in summer and another place in the winter so that it will not freeze to death. Human beings immigrate for the same reason.

(47) T5: so, do the human beings immigrate according to the seasons?

(48) S???: no teacher.

(49) T5: just a second! Okay, let us give our friend some time. Okay. The birds immigrate, that is right. They move to warmer places in winter. Then, they come back when the seasons change. So, people immigrate too. There is such a reality, right? We move. Do you think we move because of the seasons?

(50) S9: I think so (teacher)

(51) S?: (No)

(52) T5: what do you think?

(53) S17: can I say teacher? Please!

(54) T5: but my question was "What is immigration?" I did not ask why. Let us hear S6.

(55) S6: teacher, as S9 says, for example, a man does not move from Trabzon to Bayburt. Because it is generally rainy in Trabzon.

(56) S17: well, what is immigration? What? What is immigration?

(57) S6: teacher, immigration is

(58) T5: just a second! Yes S11?

(59) S11: teacher, for example, immigration means moving from one place to another. For example, I move from Bayburt to Trabzon. This is immigration.

(60) T5: so you are saying that when people move from somewhere to another for various reasons, it is immigration. Okay, do you agree?

(61) Ss: yes

(62) T5: are there any different opinions? So, almost everyone agrees. We are saying that immigration means people moving from one place to another one for various reasons. This is our general opinion.

T5 starts the lesson by asking the students what the question in the title means (lines 3-9). This question is an openended question aiming to get students' opinions and is expected to be given in interactive/dialogic discourse and the teacher does so (lines 9, 10, and 13-28). T5, following an openended question directed to the students, listens to the ideas of those who want to express ideas without making any evaluation and tries to get alternative ideas with statements such as "What do you think?" or "Are there any different opinions?" and so on. Thus, she tries to find out whether the students agree with each other and to reveal the opinions of those who disagree (interactive/dialogic). In lines 11-12, analyzed as "others," the teacher warns the students to be quiet. The investigation about the meaning of the question in the title ends when S5 starts to read the preparation question (line 29). The new question is also an open-ended question for getting students' ideas and is expected to be dealt with using interactive/dialogic discourse. Although there are students who raise their hands to answer the question, the teacher tries to establish a connection between the two subjects by first explaining the topic (noninteractive/ authoritative), then referring to the students' thoughts on the previous topic (noninteractive/dialogic) (lines 34 and 36). She starts the preparatory section that is expected to be dealt with interactive/dialogic discourse with noninteractive/authoritative and noninteractive/dialogic discourse and continues with interactive/authoritative discourse. She transforms an openended question to get students' ideas into a form that asks for information (line 38). When the student answers (lines 46 and 55) do not match with what she wants, the teacher asks the students questions (lines 47, 49, 54, and 56) to review their answers (interactive/authoritative). Since S11's answer (line 59) is close to what the teacher wants, she first gets the class to approve of it (lines 60 and 61), then gives the answer in her mind (line 62) and ends the investigation (interactive/authoritative). When this extract is evaluated in terms of communicative approach, T5 uses authoritative (interactive/ noninteractive) and dialogic (interactive/noninteractive) communicative approaches together, but uses the dialogic dimension a lot less than it should be. Figure 7 illustrates the list of problems and solutions which came up as a result of the $2^{\text {nd }}$ action plan.

3.2.3. The Third Action Cycle. The types of the communicative approach used by $\mathrm{T} 5$ in her lessons after the third action plan are shown in Figure 8 .

Figure 8 shows that she used noninteractive/authoritative $(16.96 \%)$, interactive/authoritative (17.29\%), noninteractive/dialogic (3.75\%), and interactive/dialogic $(21.83 \%)$ discourse. $40.17 \%$ of the lessons consisted of the sections described as "others." Dialogue examples regarding the discourse used in this action process are given in detail.

\section{Extract 3:}

T5: now, friends, we move on to another topic related to scientific progress. Every innovation is a contribution to our future. We will handle this subject with the past and present together. How developments have been experienced from past to present. How was it in the past? How is it today? We will deal with this. Technological developments.

T5 makes an introduction to the subject of "Every innovation is a contribution to our future" by making explanations and informing the student in this part of the course (noninteractive/authoritative). T5, after giving a brief information on the subject that she will cover in the lesson with noninteractive/ authoritative discourse, asks the students the question in the preparation section in order to get their opinions.

\section{Extract 4:}

(1) T5: well. (1.6) Yes, we will start with a question. There is an introductory question. It asks "What is the role of human needs in the emergence of technological innovations? Explain with examples." 


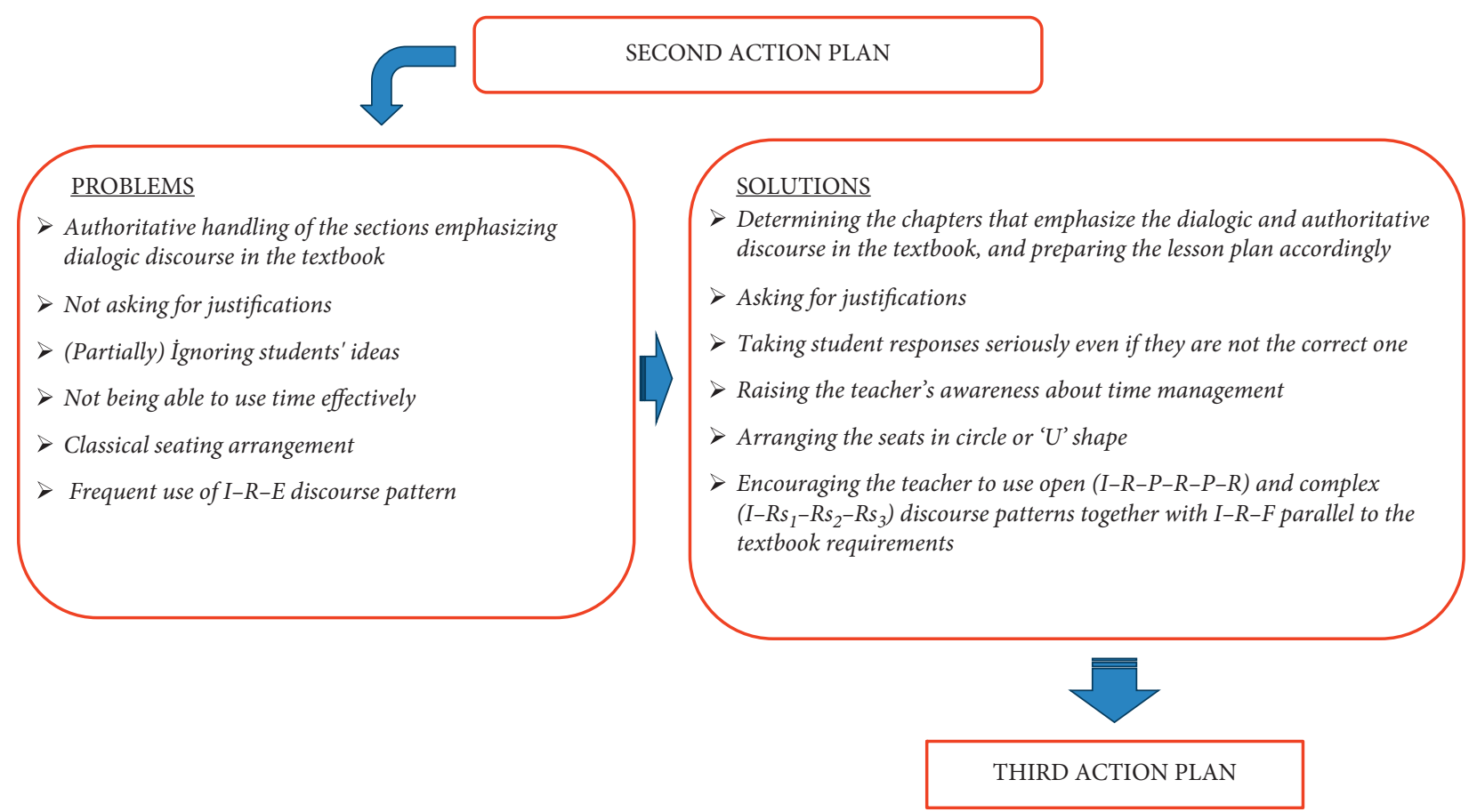

FigURE 7: $2^{\text {nd }}$ action plan-problems and solutions.

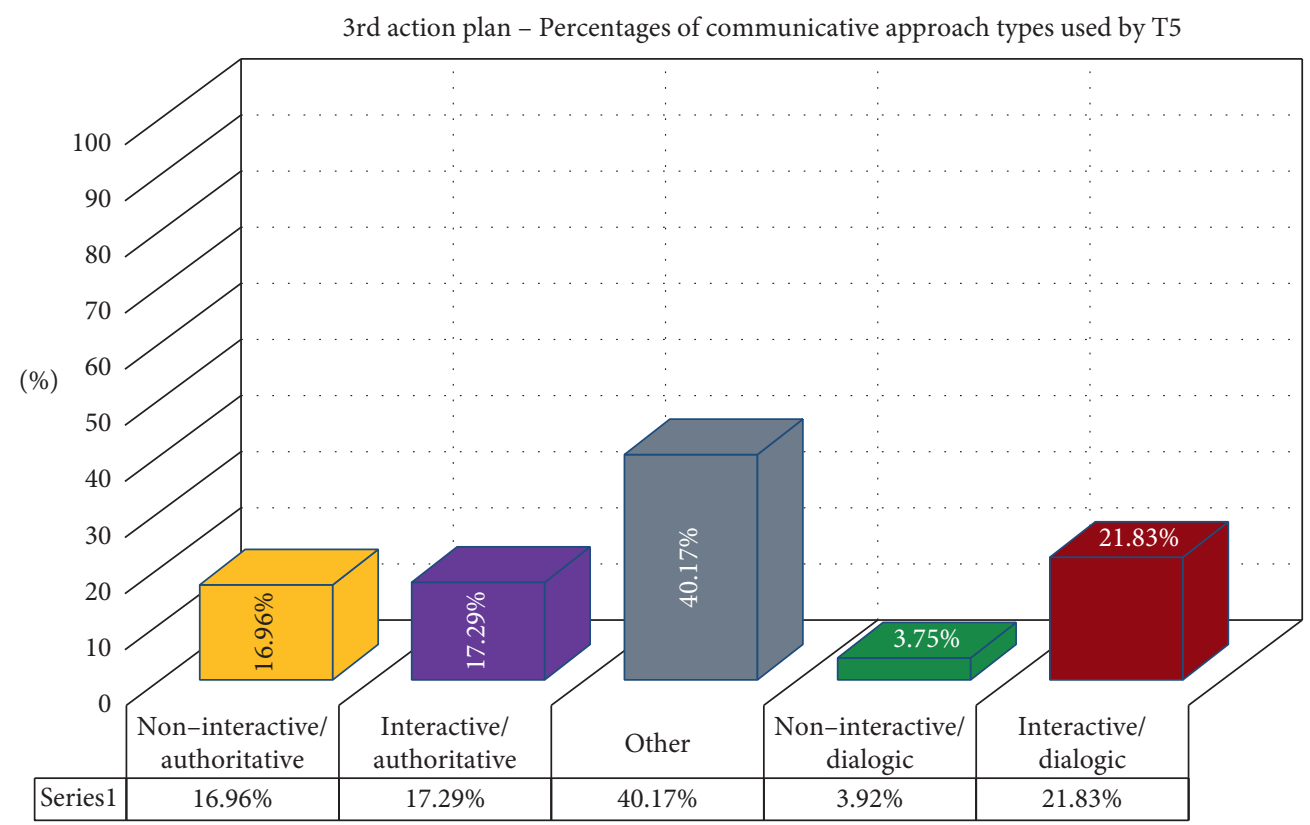

FIGURE 8: $3^{\text {rd }}$ action plan-percentages of communicative approach types used by $\mathrm{T} 5$.

Think about it first. Think about it because I want examples too.

(2) S8: I did not understand the question

(3) T5: let us read the question again. Read our question, $\mathrm{S} 2$.

(4) S2: "What is the role of human needs in the emergence of technological innovations? Explain with examples."

(5) T5: think about it. Which technological inventions have been made until today?
(6) S1: needs?

(7) T5: how did human needs affect these inventions? You will explain with an example, okay? Let us say technological inventions.

(8) S2, S8: teacher!

(9) $(2.1)$

(10) T5: (To the board) Advances, inventions. (4.6) Everybody think. I want answers from everyone. Participate in the class S5, S6 okay? Let us see, S13. (2.3) Yes, let us hear S8's answer. 
(11) S8: for example, Jazari discovered balance.

(12) T5: yes

(13) S8: for example, people used to measure length and weight with their own overarms, but now they use scales. So, there is a coherence now. They used to measure things differently. Some measured more, some less. Now, it is the same.

(14) T5: so what do you say happened to the weighing units? A standard?

(15) S8: parity.

(16) T5: A standard is reached. Our friend says that your palm and his palm are not the same size. He gave an example. He said that Jazari discovered balance. So, why did this happen?

(17) S8: teacher (people's)

(18) T5: (So why) I wonder. What was the reason that made Jazari make that discovery?

(19) S8: teacher, for example, people took less food home. He thought this was not fair and wanted to stop this unfairness.

(20) T5: our friend says the difference in weighing units. There was a difference. You were taking less, the other was taking more. Or one weighs a lot, the other weighs little. To avoid such a confusion. Yes, do you agree with that thought? (With your friend?)

(21) S6: (Yes teacher)

(22) T5: that is why Jazari discovered the balance, he said. He says the discovery of the scales is a technological breakthrough.

(23) S7: teacher

(24) T5: just a second. I will let you answer in a minute. I will write it here. What were you saying, S7?

(25) S7: teacher, (2.1) what was the name of the inventor of the telephone?

(26) (Noise)

(27) S7: (Laughing) The man who invented the telephone.

(28) S15: Graham Bell. Graham Bell.

(29) S7: teacher, Graham Bell invented the telephone. In old times, people used to communicate with smoke. Now, they speak face to face.

(30) T5: Graham Bell invented the telephone, S7 says.

(31) S7: yes

(32) T5: and he says that while people were communicating with smoke or pigeons, later on Graham Bell invented a device called telephone. Our friend gave a good example. Graham Bell invented the phone, he said. Why? Because communication was needed, he said.

(33) S16: teacher

(34) T5: just a second. I will get your answers. Calm down (Writing on the board).

(35) S17: teacher, you wrote Gram Bell.

(36) T5: communication. Just a second. The need to communicate.

(37) S17: is it not Graham Bell?

(38) T5: (Corrects her mistake) Yes S16, what will you say?
(39) S16: Galileo invented the telescope. The benefits of the telescope. Let us say they want to do research on space.

(40) T5: listen to your friend, S13, S14.

(41) S16: let us say you are looking at the sky from here. You cannot see it with the naked eye. But you can see what is in the sky with the telescope.

(42) T5: our friend says that people used to try to look with naked eyes. They tried to measure the movements of the moon, sun, stars, and planets. But later on, the telescope was invented. Human needs. Can we say that human needs are the reasons for all inventions? S1, what do you say?

T5 asks the students what they know about technological developments and gives them time to think by saying "Think about it first" (line 1). When S8 states that she did not understand the question, the teacher both makes a student read the question in the preparation section and repeats it herself (lines 3, 4, and 5). After asking the question, she again gives the students time to think and then begins to receive answers from the students. The teacher listens to the ideas of the students who want to express their ideas without any evaluation, asks sounding questions to elaborate and clarify the students' ideas, and arranges the in-class discourse according to the open chain (I-R-P-R-P-R) pattern. In addition, she echoes the student answers to make sure that all students hear them (lines 16, 20, 22, 30, 32, and 42). In sum, T5 uses the interactive/dialogic communicative approach and summarizes the student answers using the noninteractive/dialogic approach in this section.

\section{Extract 5:}

T5: we asked what roles have human needs played in the emergence of technological breakthroughs? Do technological inventions arise because of the needs of people? We said explain it by giving examples. Your friends gave some examples. We also wrote them on the board. Do you remember? Some of us mentioned the invention of writing. Someone mentioned the press. Someone said money. Another one said the compass. Someone said the steam engine. Someone said the light bulb. S6 said that money was invented, but he also said that he thought it was not meant to meet a need.

In this section, T5 sums up the student answers by referring to their previous explanations but without any interaction with them (noninteractive/dialogic).

3.3. Teacher's Views regarding the Action Process. At the end of the action research, a semistructured interview was held with the teacher who participated in the action process in order to reveal how she experienced this process. Based on the findings obtained from the interview analysis, first, codes were created, these codes were collected under appropriate categories, and finally, umbrella themes were created (See Table 2 for a detailed description of themes, categories, and codes obtained from the interviews). 
TABle 2: Themes, categories, and codes obtained from the interviews regarding the action process.

\begin{tabular}{|c|c|c|}
\hline Themes & Categories & Codes \\
\hline $\begin{array}{l}\text { Perspective on communicative } \\
\text { approach training }\end{array}$ & $\begin{array}{l}\text { Perspective on trainings } \\
\text { Perspective on the planning phase } \\
\text { Perspective on the reorganization } \\
\text { phase }\end{array}$ & $\begin{array}{l}\text { (i) Raising awareness } \\
\text { (ii) Finding trainings useful } \\
\text { (iii) Enjoying the trainings } \\
\text { (i) The effectiveness of the sample lesson design } \\
\text { (ii) Making use of the training notes and the articles } \\
\text { (i) Effectiveness of stimulated recall interviews } \\
\text { (ii) Recognising the deficiencies }\end{array}$ \\
\hline Applicability of dialogic teaching & $\begin{array}{l}\text { Necessary conditions for } \\
\text { application } \\
\text { Applicability level } \\
\text { Reasons for inapplicability }\end{array}$ & $\begin{array}{l}\text { (i) Adequacy of the teacher } \\
\text { (ii) Teacher's eagerness to professional development } \\
\text { (iii) Teacher's preparation for the lesson } \\
\text { (iv) Student levels } \\
\text { (v) Students' preparation for the lesson } \\
\text { (vi) Moderate and applicable syllabus } \\
\text { (i) Applicable for some topics } \\
\text { (ii) Applicable for all grades } \\
\text { (iii) Different levels of efficiency for different grades } \\
\text { (i) Inapplicability of some topics and learning outcomes } \\
\text { (ii) Anxiety about the curriculum content and duration }\end{array}$ \\
\hline Contribution and change & $\begin{array}{l}\text { Contribution and change for the } \\
\text { teacher }\end{array}$ & $\begin{array}{l}\text { (i) More enjoyable and efficient lessons } \\
\text { (ii) Switching from the instructor to the facilitator } \\
\text { (iii) Learning the form of education suitable for the } \\
\text { communicative approach } \\
\text { (iv) Learning to be patient with wrong answers } \\
\text { (v) Learning to listen to student ideas and to take them into } \\
\text { account } \\
\text { (vi) Being happy } \\
\text { (i) Active participation } \\
\text { (ii) Enjoying the lesson } \\
\text { (iii) Expressing his/her ideas better } \\
\text { (iv) Motivated reasoning } \\
\text { (v) Generate creative ideas } \\
\text { (vi) Offering counter arguments and refuting other ideas } \\
\text { (vii) Feeling important } \\
\text { (viii) Increased self-confidence } \\
\text { (ix) Becoming more engaged in the lesson } \\
\text { (x) Increase in student-student interaction }\end{array}$ \\
\hline Problems encountered & $\begin{array}{c}\text { Student } \\
\text { Syllabus } \\
\text { Physical condition of the } \\
\text { classroom }\end{array}$ & $\begin{array}{l}\text { (i) Inability to put the theoretical knowledge into practice } \\
\text { (ii) Heavy work load } \\
\text { (iii) Tiring } \\
\text { (i) Insufficient level of readiness } \\
\text { (ii) Inability to express his/her thoughts } \\
\text { (iv) Noise } \\
\text { (i) Incompatible curriculum and course time } \\
\text { (i) Sitting arrangement } \\
\text { (ii) Classroom size }\end{array}$ \\
\hline Suggestions & $\begin{array}{c}\text { Classroom management } \\
\text { Syllabus }\end{array}$ & $\begin{array}{l}\text { (i) Setting classroom rules } \\
\text { (i) Increasing weekly course hours } \\
\text { (ii) Easing the curriculum }\end{array}$ \\
\hline
\end{tabular}

Teacher's opinions were combined under 5 main themes: perspective on communicative approach training, applicability of dialogic teaching, contribution and change, problems encountered, and suggestions. These themes and subcategories will be discussed in the next section.

\section{Discussion and Conclusion}

4.1. The Current Situation. The current social studies curriculum uses both dialogic and authoritative discourses; the social studies textbook is prepared accordingly, but the teachers, as the implementers of the program, do not conduct their lessons accordingly. All teachers participating in the study used only authoritative (interactive/noninteractive) approaches in the social studies classroom and never included dialogic (interactive/noninteractive) ones. Molinari and Mameli [28] analyzed the question-answer sequences in classrooms (student answers and teacher inferences) in terms of the communicative approach. In this study, they observed discourse models dominating teacher 
speech. When Kanadlı [9] examined the teacher discourse before and after the communicative approach training, he found that dialogic discourse became dominant after the trainings. Pimentel and McNeil [13] found that teachers rarely use inquiry-based questions, they did not put much emphasis on student ideas, and they displayed an authoritative attitude in classroom discussions. The findings obtained in this current study are similar to the earlier results. Many of these studies reveal that authoritative (interactive/ noninteractive) discourse is dominant in classroom communication and interaction in general.

4.2. The Change in Classroom Communication and Interaction Caused by Action Plans. The problems observed at the beginning of the action process such as "authoritative handling of the sections emphasizing dialogic discourse in the textbook, the shortage of time between questions and answers, not asking for justifications, (partially) ignoring students' ideas, not listening to the student speaking, too much noise in the classroom, not being able to use time effectively, classical seating arrangement, and frequent use of I-R-E discourse pattern" were solved at the end of three action plans. The teacher completed the action process by successfully applying the trainings and solution suggestions in her lessons. At the end of the process, the interaction in the classroom increased, and the classroom communication and interaction, which were based on authoritative discourse at the beginning of the study, started to be carried out in accordance with the requirements of the textbook and the program. Literature shows that providing teachers training on the communicative approach improves the classroom discourse style and interaction atmosphere positively. For example, Lehesvuori et al. [29], who provided dialogic discourse training to preservice science teachers, observed that after the training, participants' awareness of the functions of teacher speech and alternative communication options increased. Similarly, Kanadlı [9], who examined the effect of communicative approach training on science teachers' beliefs and discourses on teacher-student roles, found that preservice teachers generally had teacher-centered beliefs using authoritative discourse in their classrooms before the training and started to use dialogic discourse by trying to form student-centered beliefs after the training. Finally, Uçak [22], Demirbağ [30], and Gizlenci [8], who examined the effects of communicative approach education on preservice science teachers, reached results that support the results of this study. Although this current study shows similarities with the literature in terms of the positive changes provided by the communicative approach education, it makes a unique contribution to the literature in terms of the field (social studies), the method (action research), and the fact that the participants are not candidates but experienced teachers.

4.3. The Teacher's Views on the Action Process. In the interview held to get her opinions on the action process, the teacher expressed her perspective on communicative approach training, applicability of dialogic teaching, contribution and change communicative approach training provided for her, and the problems she encountered and solutions. T5 stated that the communicative approach training created awareness for her, she enjoyed the training, she found the sample lesson design effective, she benefited from the training notes and articles, the stimulated recall was effective, and she realized her deficiencies in classroom communication and interaction. The results of Lehesvuori [21] and Uçak [22] about raising awareness in their work with preservice teachers coincide with our findings revealing that there is a correct proportion between the communicative approach and dialogic teaching awareness. Similar to our results, Kanadlı [9] and Lehesvuori [21] also revealed in their studies that preservice teachers reported positive opinions on communicative approach training and found the training useful and enjoyable. Parallel to the benefits mentioned by our participant, Lehesvuori et al. [29] also pointed out the importance of preparing a sample lesson design and presenting resources to the teacher, such as articles and notes. In addition, the findings of Lehesvuori et al. [29] showed that preservice teachers find video recording of the lessons, watching, and interpreting them later as useful and effective for the replanning and implementation of the lesson to coincide with our findings about the effectiveness of stimulated recall.

When asked about the applicability of dialogic teaching, the teacher stated that teachers should be well equipped and open to professional development and get prepared for the lesson well in order to apply this approach. In addition, she mentioned that the conditions such as the sufficient level of students, them being prepared for the lesson, and a manageable curriculum should be met. She stated that this approach can be applied at all grades and in most subjects, but there are differences in efficiency between grades. Pointing out the existence of some reasons preventing the implementation, the teacher listed these reasons as inapplicability of some topics and learning outcomes and anxiety about the curriculum content and duration. Lehesvuori [21] mentioned teachers who avoid dialogic activities with unpredictable results, in the point that the teacher should be well equipped. Similarly, Pimentel and McNeil [13] found that although teachers knew and accepted that classroom conversations would be different in the dialogic method, they mentioned that they lacked the necessary equipment and skills to change their approach. These all support our findings. Lehesvuori [21] and Pimentel and McNeil [13] found that teachers easily move away from dialogic discourse and shift to authoritative discourse in order to catch up with the content. There is no study in the literature that addresses the findings "teacher's preparation for the lesson, teacher's eagerness to professional development and students' preparation for the lesson" which are necessary conditions. At the point of applicability of dialogic teaching, Lehesvuori et al. [29] stated that most subjects in science are not suitable for dialogic discourse because of their direct knowledge-oriented nature. This result put forward by Lehesvuori et al. [29] and the statement "dialogic teaching can be applied in some subjects" expressed by T5 support each other. There are no supporting or contradicting studies 
for our findings on the applicability at different grades with different efficiency levels.

The teacher mentioned the contribution and change for teachers and for students separately. For the former, she mentioned the concepts of fun, production, facilitation, patience, and happiness in the classroom, and for the latter, she reported change in participation, fun, self esteem, justification, creativity, counter-argumentation, and peer interaction. Lehesvuori [21] stated that the majority of the participants acknowledge that dialogic teaching has positive contributions to the lessons in terms of making the lessons more enjoyable and productive. Our finding that the teacher has shifted from the role of teacher to the role of the facilitator is in line with the results of many studies in the literature $[9,12,14,22,31,32]$. Listening and taking the student ideas into account, which is one of the basic features of dialogic discourse frequently encountered with the transition to dialogic discourse in this study, is among the main findings of Gillies [33] and Gizlenci [8]. The contributions of using dialogic discourse to students in classroom communication and interaction and the positive change it creates are consistent with the results of other studies in the literature $[8,9,11,21,22,30,34-36]$.

T5 expressed problems in theory-knowledge mismatch, heavy work load, wearisomeness, nonpreparation, difficulty of expressing the self, noise, incompatible curriculum and course time, sitting arrangement, and classroom size. Poimenidou and Christidou [14] explained that teachers have problems with putting the theoretical knowledge into practice because they do not have sufficient theoretical knowledge and/or are inexperienced. Our finding that the practice is tiring for the teacher is supported by the statements in the study of Pimentel and McNeil [13] that authoritative discourse is more comfortable for the teacher and dialogic discourse is more demanding. Regarding noise, Lehesvuori [21] also highlighted some classroom management problems. The incompatibility between the curriculum and the course time is a common finding in most studies $[13,21,22]$. Our finding about the problems arising from the physical structure of the classroom coincides with the findings of Ateş et al. [37] that the communication between class members is negatively affected due to reasons such as crowded classrooms, the spatial structure of the classroom, and the seating arrangement.

4.4. Limitations. Of course, we are well aware of the limitation of our study being restricted to a certain number of teachers and classroom settings, but still, it does not harm the significance of the results because it still provides valuable insights into the classroom communication and interaction. Furthermore, longitudinal research on the effectiveness of the communicative approach at different educational settings such as preprimary education, high schools, and even higher education can offer a solution for the aforementioned problem of not being able to leave the traditional teaching methods and classroom atmosphere. Also, our study is limited, in which we cannot grasp the detailed student in-pair/in-group interaction in the classroom because of the limitations of the recording devices, which disable us from getting a deeper insight into the classroom interaction dynamics even when the teacher is not included in pair talk. Furthermore, the placement of the cameras and the size of the classrooms make it impossible to catch the nonverbal clues (gestures and mimes) which take a significant proportion of classroom interaction.

\section{Conclusion}

Deriving from these, it can be concluded that the communicative approach model is applicable in the social studies course. The trainings given to the teachers create awareness about the use of the communicative approach model in classroom communication and interaction and provide benefits in diversifying discourse styles. Although social studies curriculum and social studies textbook contain elements that require the use of both dialogic and authoritative discourse, it is not easy to abandon the traditional teacher-centered manner for the teacher who initially tended to either get her own thoughts approved by the students, use the question-answer method as an authority tool, use the initiation-response-evaluation (I-R-E) pattern, and make interventions to find the correct answer or only teach lessons to convey knowledge without interacting with students. After the action research, the teacher who developed in terms of diversifying the classroom discourse style started to include open-ended questions, different perspectives, initiation-response-feedback (I-R-F), open chain (I-R-P-R-P-R), and complex $\left(I-R s_{1}-R_{2}-R_{3}\right)$ discourse patterns, which are the characteristics of the interactive/dialogic approach. She also encouraged the students to reveal, justify, elaborate, and produce alternative answers. In addition, the effectiveness of the stimulated recall interviews and the sample lesson plan prepared with the teacher are among the substantial results of the study. Finally, T5's opinion on communicative approach training and the application in classroom communication and interaction are generally positive. The interview results show that this approach can be applied at all grades of social studies education when the necessary conditions are met.

Overall, this study contributes to the research body in the field of education by providing evidence for the effectiveness of communicative approach in classroom communication and interaction, which in turn improves student engagement and educational quality. We claim that our education system can greatly benefit from the inclusion of communicative approach education in teacher training programmes.

\section{Data Availability}

The access to data that support the findings of this study is restricted. The ethical approval is provided only on the condition that no one other than the researchers will see the recordings because the participants are of a vulnerable group under 18. Transcribed extracts are included within the manuscript. The interview recordings are available upon request (although in Turkish). 


\section{Disclosure}

This article was adopted from the corresponding author's $\mathrm{PhD}$ thesis completed at Atatürk University, Department of Education, under the supervision of the second author.

\section{Conflicts of Interest}

The authors declare that they have no conflicts of interest.

\section{Acknowledgments}

This research was supported by Bayburt University as the current employment of the corresponding author.

\section{References}

[1] D. Ergil, Toplum Ve Insan. [Society and Human], Turkuaz Kitabevi Yayınları, Ankara, Turkey, 1987.

[2] MoNE, "Sosyal bilgiler dersi Öğretim programı (ilkokul ve ortaokul 4-5-6 ve 7. siniflar) [social studies curriculum (primary and secondary school $4^{\text {th }}-5^{\text {th }}-6^{\text {th }}$ and $7^{\text {th }}$ grades)]," 2018, http://mufredat.meb.gov.tr/ProgramDetay.aspx? $\mathrm{PID}=354$

[3] U. Bossér and M. Lindahl, "Teachers' coordination of dialogic and authoritative discourses promoting specific goals in socioscientific issue-based teaching," International Journal of Science and Mathematics Education, vol. 19, no. 3, pp. 461482, 2021.

[4] N. Nageotte and G. Buck, "Transitioning to teaching science in higher education: exploring informal dialogical approaches to teaching in a formal educational setting," Studying Teacher Education, vol. 16, no. 1, pp. 105-122, 2020.

[5] E. F. Mortimer and P. H. Scott, Meaning Makingin Secondary Science Classrooms, Open University Press, Philadelphia, PA, USA, 2003.

[6] S. Lehesvuori, J. Viiri, and H. Rasku-Puttonen, G. Çakmakçı, M. F. Taşar, and Edt, Guiding student teachers towards more dialogic science teaching," in Contemporary Science Education Research: Scientific Literacy and Social Aspects of SciencePegem Akademi, Ankara, Turkey, 2010.

[7] C. Buty and E. F. Mortimer, "Dialogic/authoritative discourse and modelling in a high school teaching sequence on optics," International Journal of Science Education, vol. 30, no. 12, pp. 1635-1660, 2008.

[8] E. A. Gizlenci, Authoritative and Dialogic Discourse Status of Primary School Teachers Under a Professional Development Program in Mathematics Course, Turkish Council of Higher Education, Ankara, Turkey, 2019.

[9] S. Kanadll, Öğretmenlere Yönelik Hazırlanan Bir Mesleki Gelişim Programının Etkililiğinin Incelenmesi [Investigating the Effectiveness of a Professional Development Programme Designed for Teachers], Turkish Council of Higher Education Thesis Center, Ankara, Turkey, 2012.

[10] K. McMahon, "Case studies of interactive whole-class teaching in primary science: communicative approach and pedagogic purposes," International Journal of Science Education, vol. 34, no. 11, pp. 1687-1708, 2012.

[11] N. Mercer, L. Dawes, and J. K. Staarman, "Dialogic teaching in the primary science classroom," Language and Education, vol. 23, no. 4, pp. 353-369, 2009.

[12] L. Molinari, C. Mameli, and A. Gnisci, "A sequential analysis of classroom discourse in Italian primary schools: the many faces of the IRF pattern," British Journal of Educational Psychology, vol. 83, no. 3, pp. 414-430, 2012.

[13] D. S. Pimentel and K. L. McNeill, "Conducting talk in secondary science classrooms: investigating instructional moves and teachers' beliefs," Science Education, vol. 97, no. 3, pp. 367-394, 2013.

[14] M. Poimenidou and V. Christidou, "Communication practices and the construction of meaning: science activities in the kindergarten," Creative Education, vol. 01, no. 02, pp. 81-92, 2010.

[15] P. H. Scott, E. F. Mortimer, and O. G. Aguiar, "The tension between authoritative and dialogic discourse: a fundamental characteristic of meaning making interactions in high school science lessons," Science Education, vol. 90, no. 4, pp. 605-631, 2006.

[16] E. B. Turhan, Monolojik Öğretim Yapan Bir Fen Öğretmeni Ile Diyalojik Öğretim Yapan Bir Fen Öğretmenin Öğretim Söylemi Açısından Kıyaslanması [Comparing Monologic and Dialogic Science Teachers in Terms of Their Science Teaching Discourse], Turkish Council of Higher Education Thesis Center, Ankara, Turkey, 2019.

[17] H. Ulu, "Dördüncü sınıf fen ve teknoloji derslerinin diyalojik öğretim açısından analizi üzerine bir araştırma.[a research study on the analysis of the fourth grade science and technology course in terms of dialogic teaching]," Ana Dili Eğitimi Dergisi, vol. 5, no. 4, pp. 608-626, 2017.

[18] C. D. Van Booven, "Revisiting the authoritative-dialogic tension in inquiry-based elementary science teacher questioning," International Journal of Science Education, vol. 37, no. 8, pp. 1182-1201, 2015.

[19] M. Vrikki, L. Wheatley, C. Howe, S. Hennessy, and N. Mercer, "Dialogic practices in primary school classrooms," Language and Education, vol. 33, no. 1, pp. 85-100, 2019.

[20] J. J. Watters and C. M. Diezmann, "Engaging elementary students in learning science: an analysis of classroom dialogue," Instructional Science, vol. 44, no. 1, pp. 25-44, 2016.

[21] S. Lehesvuori, "Towards dialogic teaching in science: challenging classroom realities through teacher education," Jyvaskyla Studies in Education, Psychology and Social Research, vol. 9, no. 2, 2013.

[22] E. Uçak, Öğretmen Adaylarının Fen Öğretiminde Kullandıkları Iletişimsel Yaklaşım Türleri [Communicative Approach Types Used by Preservice Teachers' in Science Teaching], Turkish Council of Higher Education Thesis Center, Ankara, Turkey, 2014.

[23] I. M. Holter and D. Schwartz-Barcott, "Action research: what is it? how has it been used and how can it be used in nursing?" Journal of Advanced Nursing, vol. 18, no. 2, pp. 298-304, 1993.

[24] A. P. Johnson, A Short Guide to Action Research, Allyn and Bacon, Boston, MA, USA, 2008.

[25] M. Q. Patton, Qualitative Research \& Evaluation Methods: Integrating Theory and Practice, Sage Publications, Thousand Oaks, CA, USA, 2014.

[26] E. Sözen, "Söylem: belirsizlik, mübadele, bilgi/güç, ve refleksivite [discourse: uncertainty, exchange, knowledge/ power and reflexivity]," Paradigma Yayınları, İstanbul, Turkey, 1999.

[27] M. B. Miles and A. M. Huberman, Qualitative Data Analysis, Sage Publications, Thousand Oaks, CA, USA, 2nd edition, 1994.

[28] L. Molinari and C. Mameli, "Classroom dialogic discourse: an observational study," Procedia-Social and Behavioral Sciences, vol. 2, no. 2, pp. 3857-3860, 2010. 
[29] S. Lehesvuori, J. Viiri, and H. Rasku-Puttonen, "Introducing dialogic teaching to science student teachers," Journal of Science Teacher Education, vol. 22, no. 8, pp. 705-727, 2011.

[30] M. Demirbağ, "Otoriter ve diyalojik söylem tiplerinin fen bilgisi öğretmen adaylarının argüman gelişimine etkisi [the effects of authoritative and dialogic discourses on pre-service science teachers' argument development]," Uludăg Üniversitesi Eğitim Fakültesi Dergisi, vol. 30, no. 1, pp. 321340, 2017.

[31] A. Akış, Otoriter Ve Diyalojik Öğretmenlerin ÖğretmenÖğrenci Rollerine Dair Beklenti Ve inançları. [Authoritarian and Dialogical Teachers? Expectations and Beliefs about Their Own and Students' Roles], Turkish Council of Higher Education Thesis Center, Ankara, Turkey, 2012.

[32] O. N. Kaya and Z. Kılıç, "Fen sinıflarında meydana gelen diyaloglar ve öğrenme üzerine etkileri [types of dialogs and their effects on learning in science classrooms]," Kastamonu Eğitim Dergisi, vol. 18, no. 1, pp. 115-130, 2010.

[33] R. M. Gillies, "Dialogic interactions in the cooperative classroom," International Journal of Educational Research, vol. 76, pp. 178-189, 2016.

[34] B. Baykal, Fen Ve Teknoloji Dersi Öğretmenlerinin Sınıf Içi Iletişim Ve Etkileşimlerinin Analizi: Diyalojik Ve Otorirer Tartışmalar [the Analysis of Classroom Communications and Interactions of Science and Technology Teachers: Dialogic and Authoritative Discourses], Turkish Council of Higher Education Thesis Center, Ankara, Turkey, 2014.

[35] A. Bozkurt and S. Polat, "Examining teacher questions to reveal students' mathematical thoughts," Turkish Journal of Computer and Mathematics Education (TURCOMAT), vol. 9, no. 1, pp. 72-96, 2017.

[36] C. Gürel, H. Olgun, E. Süzük, and Z. Gürel, "Discourse analysis of the arguments developed in model rocketry learning environment [discourse analysis of the arguments developed in model rocketry learning environment]," International Online Journal of Educational Sciences, vol. 6, no. 1, 2014.

[37] S. Ateş, Y. Döğmeci, E. Güray, and F. F. Gürsoy, "Sınıf içi konuşmaların bir analizi: diyalojik mi monolojik mi? [an analysis of speeches of classroom inside: is it dialogic or monologic?]," Journal of Kirsehir Education Faculty, vol. 17, no. 2, pp. 603-625, 2016. 